Volume 9 No.2, March - April 2020

International Journal of Advanced Trends in Computer Science and Engineering

Available Online at http://www.warse.org/IJATCSE/static/pdf/file/ijatcse191922020.pdf

https://doi.org/10.30534/ijatcse/2020/191922020

\title{
Information System for Integrative and Dynamic Railway Supply Chain Management
}

\author{
Mailasan Jayakrishnan ${ }^{1}$, Abdul Karim Mohamad ${ }^{1}$, Mokhtar Mohd Yusof ${ }^{2}$ \\ ${ }^{1}$ Centre for Advanced Computing Technology, Faculty of Information \& Communication Technology, Universiti \\ Teknikal Malaysia Melaka, Hang Tuah Jaya, 76100, Durian Tunggal, Melaka, Malaysia, \\ m031620010@student.utem.edu.my, karim@utem.edu.my \\ ${ }^{2}$ Faculty of Computer and Information Technology, Al-Madinah International University, Pusat Perdagangan \\ Salak 2, No.18, Jalan 2/125e, Taman Desa Petaling, 57100 Kuala Lumpur, Malaysia, \\ mukhtar.yusuf@mediu.edu.my
}

\begin{abstract}
Information System is been utilized to facilitate the communication and decision-making processes within an industry and has recently been used by industry as a strategic weapon against their supply chain management. Information System is a multidisciplinary and comprehensive domain that integrated high-performance systems in an industry with diverse competencies that underpin knowledge and decision-making skill outcomes. The industry is managed and structured to converge the requirement to tail collective objectives. Optimizing decision-making processes has become a crucial element for an industry nowadays. The industry has a management complex that ascertains the relation between the divergent supply chain venture and goals. Besides, it needs an impact decision-making process that is reliable and analysis of future trends for the industries supply chain management. Therefore, integrative and dynamic IS perspectives need to be an emphasis on thinking and acting in making the decision-making process and support value creation for the industry. In this paper, we have conceptualized the integrative and dynamic IS perspective that the industry needed in their supply chain management towards digitalization value. Improving the decision-making process is the key success for industry performance and enables better mitigation of Information System activities with supply chain management. The paper emphasis case study in the Railway Industry area.
\end{abstract}

Key words: Decision Making, Digitalization, Information System, Supply Chain Management, Railway Industry.

\section{INTRODUCTION}

Industry leaders should take the Information System (IS) more seriously as a truly strategic discipline [1]. They should implement the right skill set and mindset, as their key enabler to see IS being practiced and applied [2]. IS must enable the technology culture to thrive within the Industry community
[3]. IS implementation, integration and design being centerpiece for the industry and technology revolution [4]. Besides the utilization of Information and Communication Technology (ICT) as a key enabler element of the industry in the $21^{\text {st }}$ century that draws the attention by applying IS tools in doing their daily business [5]. Therefore, we need to manage a complex IS that can understand the functions and boost the industry potentials. The industry of all sizes are looking to IS to better integrate with industry performance, supply chain management and provide strategic decision-making advantages [6]. Moreover, they need the right information base for decision making that provides information reliably and strategic decision-making processes [7]. Yet, IS boost industry potential through engagement with the technology and contribute to economic and society within national boundaries. Hence, IS aligns industry objectives with a technology infrastructure that improves key features and performance towards the future state and evolution context [8]. IS context could significantly improve the quality performance, employability and profitability through technology transfer and identify the solution that will impact the industry and enhance their performance [9].

Improving decision making in an industry needs the opportunity of IS to transform its performance [10]. Therefore, IS transformation providing an opportunity for the industry function to become a more efficient and better support decision-making tool [11]. This tends to start with formulating industry strategies. Furthermore, the provision of management information can provide exciting new opportunities to the industry development [12]. We can emphasize the duality of IS and rethinking the concept of IS on industry towards integrative and dynamic context. Yet, we need to implement IS as its outcome for strategic choice and industry action towards determining the impacts on industry structure and performance. We are proposing an integrative and dynamic IS perspective model that industry needed in their supply chain management towards digitalization value between the technology and industry performance. Thus, the integration of the overall structure of the IS model in the industry will be a useful and essential role in the execution of the strategy for future value oriented. 


\section{INFLUENCES OF INFORMATION SYSTEM PERSPECTIVE}

The adoption of IS in the industry is surge as pioneers for competitive advantages and efficiency towards digital transformation [13]. The impact of IS towards the industry is creating an opportunity for new technologies or information knowledge that might offer the strategies, limitations, and risks of change within the industry performance [14]. The industry has been identified as one of the key contributions to the national economy in a significant way. Therefore, IS can increase the profitability of the industry through digitalizing decision-making system aspiration outlined [15]. Hence, the industry needs to direct and focus through IS initiatives and activities to help the country achieve the aspiration towards digitalization. IS must be designed in such a way that the industry will align its vision and mission to the national aspiration [16]. In Malaysia, the national aspiration is to focus on Shared Prosperity Vision 2030 that focuses on industry sustainable growth along with the technology revolution and enhancing the nation's prosperity. Therefore, IS define as an interfacing hub that facilitates industry development [17]. Besides IS will be the center for the industry on encompassing knowledge transfer and digital transformation. Digital transformation can impact the market through competitive pressure and IS development through the globalization of industry function [18]. IS development focus on tools and instruments that industry use in their productive activities. Moreover, IS implementation as technology transformation and the industrial activities that were design based on this perspective for better outcome and trigger of structural change within the industry [19]. Yet IS acts as an intervention between industry structure and decision-making process for potential outcomes that guide towards the possible changes in the future [20]. Therefore, we need to look at IS as a set of tools that enables the industry to transform their performance data into accurate information that can benefit their decision-making process. Information System tools are used for transformation on enhancing industry governance, strengthening industry future pathways, enhancing industry income generation, enhancing industry efficiency and productivity, and strengthening industry supply chain performance management on a comprehensive knowledge-based economy. Thus, IS reflects as data-based importance to transformation of the industry towards improving their operative performance, competitive advantage, increasing profitability and creating value-added to build a strong fundamental through evaluation metrics and appropriate assessment that can integrate diversity among industries. IS will drive industry excellence and allows for excellence in certain functions that facilitate the industry Key Performance Indicator (KPI). Hence, we have tabulated the influences of IS towards industry context, as shown in Table 1.

Table 1: The Influences of Information System towards Industry context

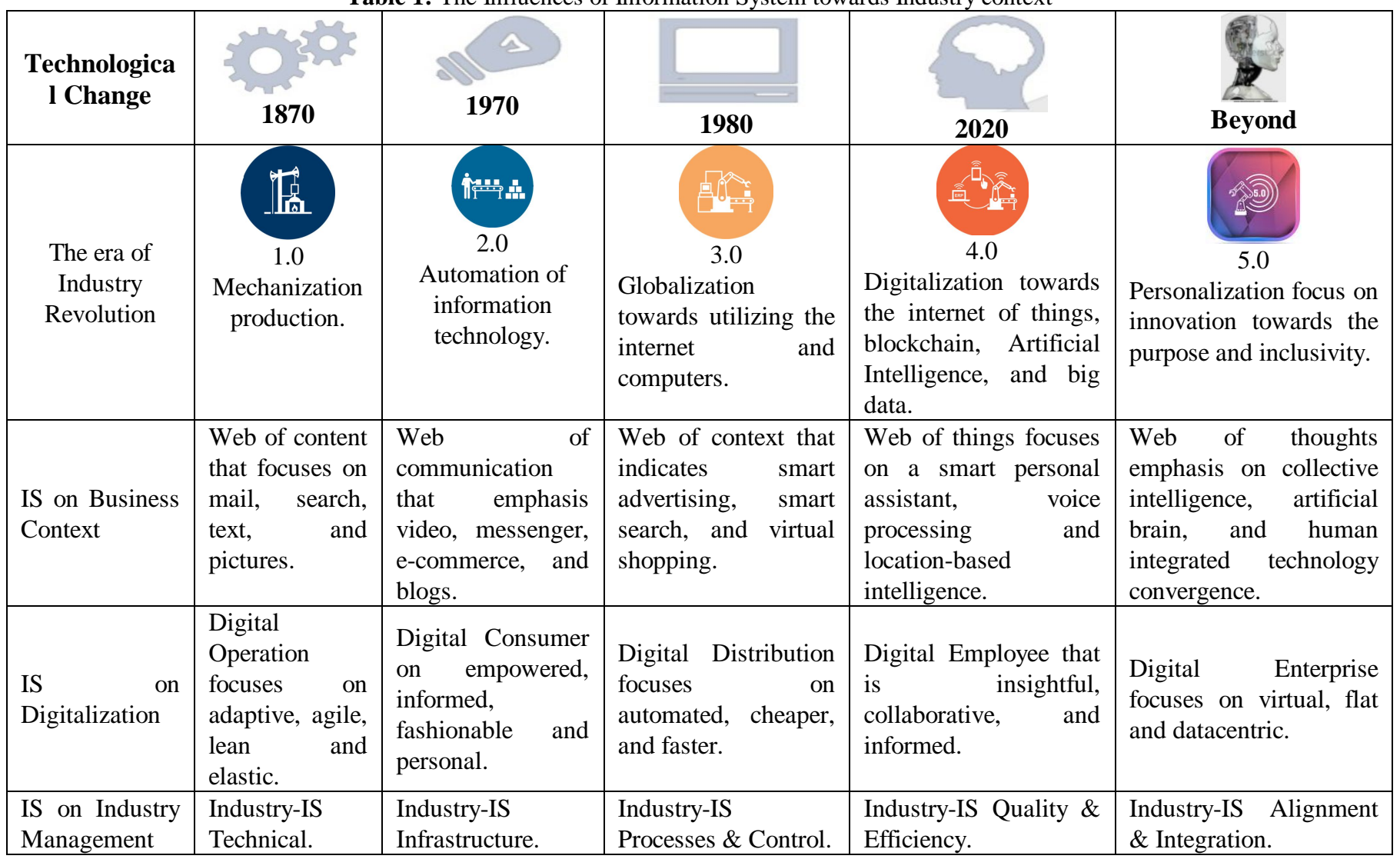


Table 1 indicates the influences of IS towards industry context that need to focus on increasing the industry access in the technology transformation and enhancing industry productivity towards cost efficiency. IS will reflect the new strategic direction for industry through evaluating the current IS instrument and develop an instrument according to the industry needs and implement rating level on strategized outcomes [21]. The IS develops this way will be contextualized and enhanced the industry decision-makers on generating knowledge that can be worn for a well-informed decision-making action [22]. IS enabled and constrained the structures of the industry that resulted from the previous information action.We intend to expound the possible and value-adding quality of IS and supply chain for use within the modernized forward-thinking industry. Yet, we provide a contemporary illustration of leading-edge on IS towards industry context within the discipline of SCM. Moreover, we focus the IS application on implementation through logical thinking on the data to specify the industry action for better decision-making processes specifically in optimization that tackle more complex dilemmas and heuristics approach in the optimal decision. We were intent to also investigate at information processing and control model of Cybernetics with the use of Stafford Beer's Viable System Model (VSM). Through VSM the organization is transforming into an autonomous system capable of adapting to those constant environment changes. VSM also exhibits many other features including spontaneous behavior and social harmony within hierarchically ordered relationships.

\section{SUPPLY CHAIN MANAGEMENT PERSPECTIVE}

Industries have tried to design an effective IS models for high-quality Supply Chain Management (SCM). The emerging innovations in an industry needed are for their SCM [23]. Many industrial in Malaysia have integrated and adopted IS for their strategic approach to SCM focusing on logistics management and purchasing [24]. SCM can be justified as a holistic IS approach that utilizes to monitor the life cycle of the supply chain of an industry. In the $21^{\text {st }}$ century, SCM has become a significant strategic tool for the industry to manage their quality and competitive advantage that needs the implementation of IS [6]. Yet SCM emphasis the importance of integrated activities in the industry that add value to the outcomes.

The components of the supply chain can be justified as (1) Sourcing and Procurement focus on analyzing the capabilities of potential suppliers and craft the sourcing strategy [25], (2) Supply Chain Planning emphasis on the industry forecast and sales data that able to react more quickly when changes in demand occur [26], (3) Logistics and Information Management focus on managing the complexity of the supply chain process that is reliable and profitability [27] and (4) Warehousing and Transportation emphasis on efficient management to move the right product to the location [28]. Therefore, we need to develop an IS platform that emphasis managing the component of the supply chain in a digitalization view for a strategic decision-making process that yields maximum profit.

SCM is a very important part of the industrial process that need to decide their operation strategy. Thus, the supply chain needs a continuous flow of information through many levels in the industry. Hence IS application is needed to understand the information properly and timely disseminated towards a knowledge-based economy and prospect the industry itself. We are transforming SCM from multiple internal and external sources into IS insights for making better planning decisions that empower supply chain decision-makers on scenario analysis and optimization. Supply chains are getting faster and we should focus on IS analytics capabilities that support the decision-making process. Therefore, we have tabulated the supply chain management in the IS analytics theme that drives faster decision-making process, as shown in Table 2.

Table 2: The Supply Chain Management in Information System Analytics context

\begin{tabular}{|c|c|c|c|c|c|}
\hline $\begin{array}{c}\text { Information } \\
\text { System } \\
\text { Analytics }\end{array}$ & $\frac{-8+8 \%}{\text { Data }}$ & Analyze & Insight & Decide & 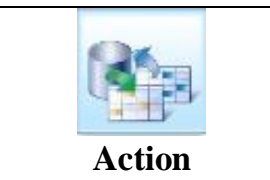 \\
\hline $\begin{array}{l}\text { Supply Chain } \\
\text { Value }\end{array}$ & $\begin{array}{c}\text { Descriptive Analytics } \\
\text { (What happened } \\
\text { when?) }\end{array}$ & $\begin{array}{c}\text { Inquisitive Analytics } \\
\text { (Why it happened } \\
\text { then?) }\end{array}$ & $\begin{array}{c}\text { Predictive Analytics } \\
\text { (What will happen } \\
\text { when I change the } \\
\text { process?) }\end{array}$ & $\begin{array}{c}\text { Prescriptive } \\
\text { Analytics } \\
\text { (What should I have } \\
\text { to change?) }\end{array}$ & $\begin{array}{c}\text { Pre-emptive } \\
\text { Analytics } \\
\text { (What can I do or } \\
\text { change more?) } \\
\end{array}$ \\
\hline $\begin{array}{l}\text { Supply Chain } \\
\text { Enablers }\end{array}$ & $\begin{array}{c}\text { Dashboard-Information } \\
\text { (Measure) }\end{array}$ & $\begin{array}{l}\text { Scorecards-Insight } \\
\text { (Analyze) }\end{array}$ & $\begin{array}{l}\text { Industry } \\
\text { reporting-Insight } \\
\text { (Predict) }\end{array}$ & $\begin{array}{l}\text { Forecasting-Decision } \\
\text { (Act) }\end{array}$ & $\begin{array}{l}\text { Simulation-Actions } \\
\text { (Decide) }\end{array}$ \\
\hline $\begin{array}{l}\text { Supply Chain } \\
\text { Outcomes }\end{array}$ & $\begin{array}{l}\text { Defined the problems } \\
\text { from the past. }\end{array}$ & $\begin{array}{l}\text { Define the } \\
\text { opportunities from the } \\
\text { past. }\end{array}$ & $\begin{array}{l}\text { Ability to identify the } \\
\text { root cause of the } \\
\text { current dilemma. }\end{array}$ & $\begin{array}{l}\text { Accurate the } \\
\text { condition for the } \\
\text { future. }\end{array}$ & $\begin{array}{l}\text { Suggest the best } \\
\text { possible prospect } \\
\text { for the long term. }\end{array}$ \\
\hline
\end{tabular}


Mailasan Jayakrishnan et al., International Journal of Advanced Trends in Computer Science and Engineering, 9(2), March - April 2020, 2159 - 2167

\begin{tabular}{|c|c|c|c|c|c|}
\hline $\begin{array}{l}\text { Supply Chain } \\
\text { Intelligence } \\
\text { Approach }\end{array}$ & $\begin{array}{l}\text { Automated reporting } \\
\text { (Purchasing and } \\
\text { Logistics reporting) }\end{array}$ & $\begin{array}{c}\text { Ad hoc analysis } \\
\text { (Process definition and } \\
\text { functional } \\
\text { identification) }\end{array}$ & $\begin{array}{l}\text { Statistical modeling } \\
\text { the scenarios } \\
\text { (Process Alignment } \\
\text { Supply Chain } \\
\text { Improvements) }\end{array}$ & $\begin{array}{c}\text { Holistic optimization } \\
\text { (Unified Supply } \\
\text { Chain Strategy) }\end{array}$ & $\begin{array}{c}\text { Insight Actions } \\
\text { (Virtual Supply } \\
\text { Chains) }\end{array}$ \\
\hline
\end{tabular}
analytics context that focuses on analytics for deriving insights from data to make a strategic decision-making process. We need to mature our new way of thinking to analyze the industry process. SCM in today's phenomena needs to start with measuring the situation and ending up with long-term decision making that benefits the industry itself. Moreover, it should offer more value in the supply chain management IS that can optimize the industrial activity and enables the industry to examine its previous, optimize its current, predict its upcoming and analyze its hub premise.

We need to emphasis on data-intensive of the industrial processes that justify the data complexity of the supply chain itself. Besides IS needed to prevent and anticipate potential risk factors that can impact the industry performance. Therefore, we need to implement IS to enhance the supply chain performance in the industry especially the Railway Industry (RI) to be more measurable and transparent by exposing the variability of potential issues and opportunities that might the industry faces. Descriptive analytics will measure the relationship between the supplier and approaches that need to take in the future by looking into the data to describe the current situation of the patterns, trends, and expectations of the RI.

Inquisitive analytics can be justified as diagnostic analytics that determines the real reasons for the poor performance of the RI and provides corrective action on the supply chain that can increase the RI performance. Predictive analytics provides an estimation of the future result of the supply chain process and discover the risks and opportunities in the future

through optimizing RI process performance and prescribing specific decision making and action taken for the future. The prescriptive analytics improves the decision making and optimize the supply chain planning of RI through advising possible outcomes and suggested actions that need to be taken by the decision-makers for better performance and profitability of the RI. Pre-emptive analytics focuses on the important insights of the RI by providing the path of the desired outcome and actionable results that can optimally supply chain decisions. Therefore, supply chain management in the IS analytics context will drive insights from supply chain value that employs advanced forecasting tools to generate the highest priority supply chain dilemmas. We are combining SCM and IS analytics into one integrated platform that drive insights for smarter supply chain decision making

\section{INTEGRATIVE AND DYNAMIC INFORMATION SYSTEM PERSPECTIVE}

The adoption of digitalization in the industry is stimulated as pioneers signify the fundamental competitive advantages and efficiency that digital transformation provides. Industry requires measurable outcomes on their digital transformation on their SCM that requires a new mindset. We need a mindset that introduces digital capabilities and skills into strategic thinking and applies new approaches to create specialized IS techniques that enable the sustainable integrative and dynamic transition into smart, digitalized SCM. The role of digitalization in terms of the interaction between IS and technology that hence as both structural for SCM constructed.

Integrative and dynamic perspective emphasis on continues learning within the industry, where SCM share learning through applying and creating knowledge in their decision-making process. Besides knowledge generation and sharing that occurs through integrative on sharing knowledge about SCM and crating new strategies in their decision-making process. Moreover, the industry able to emphasize critical systematic thinking that encouraged the SCM to think in new approaches and assumptions in their decision-making process. IS placed new tools into the hands of an industry to help them deal with the rapid pace of supply chain growth and diversification [29].

In industry, the explosive growth of digital empowers decisions that give a competitive edge [30]. An integrative and dynamic IS perspective will bring the industry into a new level, both inside and outside of the industry with multiple decision-making processes. Many academics, practitioners, researchers, and students need a strategic understanding of developing a supply chain management system or software to mimic to respond and behave in a circumstance for the decision-making process within an industry. The computer-based analytical process with decision-making behavior and actions that consider intelligence is a need in the current SCM. Yet, emphasizing the integrative and dynamic IS perspective will increase the insights and visibility to create a critical decision in the SCM. This conceptualizes integrative and dynamic IS perspective will entail various new skills and cross-functional to break down the industry silos that still exist in their SCM. Hence these integrative and dynamic IS perspectives will be using advanced simulations and skill-based decision-making systems for SCM. Moreover, 
it focuses on enabling IS to make accurate predictions on any type of data on the supply chain that performing the system to solve a problem by looking into the previously solved problem and identify the steps for the solution for the industry SCM.

Our intention focusses on a system that learns from a set of data as knowledge and uses it for executing the plan of solution for the industry in the SCM concept on IS value.
Besides, it helps the industry to transform into a technological advancement that utilizes an appliable system in their SCM for fostering the growth of the industry. Therefore, we have tabulated the supply chain management towards digitalization value, as shown in Table 3 for IS the technological foundation of an industry advantage towards adopting new technology in their decision making.

Table 3: The Supply Chain Management towards Digitalization Value

\begin{tabular}{|c|c|c|c|c|c|}
\hline $\begin{array}{c}\text { Information } \\
\text { System Value }\end{array}$ & 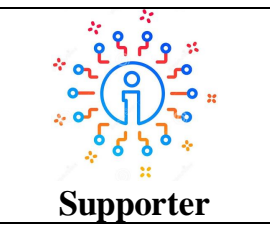 & Cost Cutter & Enabler & Driver & GameChanger \\
\hline $\begin{array}{c}\text { Supply Chain } \\
\text { Value }\end{array}$ & $\begin{array}{l}\text { Reactive Tactical } \\
\text { (Level 1-Endorse } \\
\text { Ad-Hoc Action) }\end{array}$ & $\begin{array}{l}\text { Proactive Tactical } \\
\text { (Level 2-Pledge } \\
\text { Action) }\end{array}$ & $\begin{array}{l}\text { Reactive Strategic } \\
\text { (Level } \\
\text { 3-Prevailing Fixed } \\
\text { Action) }\end{array}$ & $\begin{array}{c}\text { Proactive Strategic } \\
\text { (Level 4-Surpass Direct } \\
\text { Action) }\end{array}$ & $\begin{array}{c}\text { Digitalization } \\
\text { Strategic } \\
\text { (Level 5-Optimised } \\
\text { Action) } \\
\end{array}$ \\
\hline $\begin{array}{c}\text { Digitalization } \\
\text { Value }\end{array}$ & $\begin{array}{l}\text { IS maintenance } \\
\text { that maximizes } \\
\text { efficiency for } \\
\text { representational } \\
\text { value for industry } \\
\text { better } \\
\text { management } \\
\text { decisions. }\end{array}$ & $\begin{array}{l}\text { IS consolidation for } \\
\text { the meaningful way } \\
\text { that determines } \\
\text { strategic industry } \\
\text { advantages. }\end{array}$ & $\begin{array}{l}\text { Technology } \\
\text { maintenance that } \\
\text { facilitates industry } \\
\text { transactions for } \\
\text { the collaboration } \\
\text { system and } \\
\text { real-time } \\
\text { processing. }\end{array}$ & $\begin{array}{l}\text { IS innovation that } \\
\text { enabling process } \\
\text { control for improving } \\
\text { and } \\
\text { information as an } \\
\text { enterprise collaboration } \\
\text { system for decision } \\
\text { making. }\end{array}$ & $\begin{array}{l}\text { Industry } \\
\text { transformation that } \\
\text { turned into learning } \\
\text { that can interpret } \\
\text { the past and guide } \\
\text { future action. }\end{array}$ \\
\hline $\begin{array}{c}\text { Value } \\
\text { Proposition }\end{array}$ & $\begin{array}{l}\text { Future Proof of } \\
\text { practices and } \\
\text { lessons learned. }\end{array}$ & $\begin{array}{l}\text { Improve Efficiency } \\
\text { in industry and } \\
\text { technology } \\
\text { strategies. }\end{array}$ & $\begin{array}{l}\text { Informed Decision } \\
\text { Making that aligns } \\
\text { IS strategy } \\
\text { development in the } \\
\text { industry. }\end{array}$ & $\begin{array}{l}\text { Centralized IS on } \\
\text { information sharing } \\
\text { and exchange with the } \\
\text { integrated } \\
\text { decision-making } \\
\text { process. }\end{array}$ & $\begin{array}{l}\text { Evidence-based } \\
\text { Traceability that } \\
\text { optimization } \\
\text { transformation } \\
\text { within data-driven } \\
\text { in the industry. }\end{array}$ \\
\hline $\begin{array}{l}\text { Pathway } \\
\text { Value }\end{array}$ & $\begin{array}{l}\text { Data presented in } \\
\text { a way that helps } \\
\text { the industry } \\
\text { understand the } \\
\text { specific context. }\end{array}$ & $\begin{array}{l}\text { Information } \\
\text { consumption on the } \\
\text { industry that targets } \\
\text { the outcomes. }\end{array}$ & $\begin{array}{l}\text { Knowledge turns } \\
\text { into useful } \\
\text { information that } \\
\text { supports a specific } \\
\text { task for decision } \\
\text { making. }\end{array}$ & $\begin{array}{l}\text { Insight upon the latest } \\
\text { information available } \\
\text { for decision making } \\
\text { perspective. }\end{array}$ & $\begin{array}{l}\text { Wisdom obtaining } \\
\text { through the } \\
\text { information } \\
\text { involved in decision } \\
\text { making. }\end{array}$ \\
\hline
\end{tabular}

Based on Table 3, supply chain management towards digitalization value emphasis on optimization of the industry performance. We are looking into the future trend in supply chain transportation in RI, where operations will be fully mechanized, automated, and sustainable with the use of IS, digital technologies and efficient technology convergence will revolutionize RI. Yet enabling IS to become far more deeply ingrained in RI for exchange of knowledge that shifts supply chain norms that make harnessing the new technologies possible and willingness to adopt it. Moreover, the supply chain management towards digitalization value will contribute to the growth of innovation within the RI.

Our point of view considering the digitalization value as a structural property of RI that emphasis multiple levels of
SCM and knowledgeable towards the decision-making process. IS are created and changed based on industry action, yet it is also utilized by decision-makers to accomplish some action in their SCM. Therefore, our mindset towards RI is embedded in sustainable SCM towards a digital transformation that benefits the industry through increasing revenue outcomes by enabling IS technologies. This SCM towards digitalization value will perform real-time performance-data analysis for RI and the new generation of digitalized technology to enhance the overall performance of RI supply chain management through the virtualized decision-making process.

We are conceptualizing the key points of supply chain management towards the digitalization value and automation pioneering industry towards the new wave of digitalized technology. The drivers of value should focus on improving 
planning and forecasting the supply chain performance, reducing time to market, improving competitive capabilities and drive commercial value in a real-life context. The starting point for deriving measurable value is from digitalization. Thus, the industry needs to invest in digital technology that can enable them for competitiveness to transmit real-time supply chain performance data to an integrated control system that can optimize the performance of the industry.

We need to design and develop a powerful supply chain decision-making system model with strategic data analytics and supply chain capabilities for decision-makers, practitioners, researchers, and students that can utilize and improve the efficiency of IS insights. Yet, this model should provide a solid foundation for applications and data-based systems on predictive and optimization on the industry performance. Hence, it should digitally link data across the enterprise in the supply chain and improve planning and forecasting towards competitive advantages that predicted fluctuations in market demand. To achieve operational excellence, the optimization of the IS supply chain management value chain is an industry imperative. The supply chain needs to be integrated.

Therefore, we have adopted the viable system model for designing an integrative and dynamic IS perspective model for supply chain management practically. Viable System Model (VSM) emphasis on management tool to determine the viability of industry towards technology flexibility [31]. Besides, it is a holistic model that capable of dealing with issues of industry structure, focusing on environment-the surroundings within which other elements function, operation-elements which do things, and management-elements which control operations. VSM is formulated for an industrial system that identifies the problems and re-design industry systems for better performance [32]. There are five subsystems in the VSM that mapped onto the various aspect of an industry structure [33]. VSM defines the systemic structure of the supply chain and components the collaboration on the key points of IS that must be considered. We have tabulated the subsystem for supply chain management based on VSM, as shown in Table 4.

Table 4: The Subsystem for supply chain management based on the viable system model

\begin{tabular}{|c|c|c|c|c|c|}
\hline Subsystems & $\begin{array}{c}\text { System 1 } \\
\text { (Implementation) }\end{array}$ & $\begin{array}{c}\text { System 2 } \\
\text { (Coordination) }\end{array}$ & $\begin{array}{l}\text { System } 3 \\
\text { (Control) }\end{array}$ & $\begin{array}{c}\text { System 4 } \\
\text { (Intelligence) }\end{array}$ & $\begin{array}{c}\text { System } 5 \\
\text { (Policy) }\end{array}$ \\
\hline $\begin{array}{l}\text { Requisite } \\
\text { Variety }\end{array}$ & $\begin{array}{l}\text { Focuses on the } \\
\text { primary operation } \\
\text { of the industry. }\end{array}$ & $\begin{array}{l}\text { It allows the } \\
\text { operation managed } \\
\text { to interact. }\end{array}$ & $\begin{array}{l}\text { The vast perspective of } \\
\text { all the activities that } \\
\text { integrated with the } \\
\text { industry. }\end{array}$ & $\begin{array}{l}\text { Provides information } \\
\text { regarding the industry } \\
\text { current form. }\end{array}$ & \begin{tabular}{lr}
\multicolumn{2}{|c}{ Encompassing all } \\
decision making \\
within \\
industry.
\end{tabular} \\
\hline $\begin{array}{c}\text { Fragmentatio } \\
\mathrm{n} \text { element }\end{array}$ & $\begin{array}{l}\text { Operations indicat } \\
\text { management of } \\
\text { process and unde } \\
\text { problem. }\end{array}$ & $\begin{array}{l}\text { e the fundamental } \\
\text { the implementation } \\
\text { stand to solve the }\end{array}$ & $\begin{array}{l}\text { Management defines } \\
\text { the control of the } \\
\text { internal and immediate } \\
\text { activities of the } \\
\text { industry performance. }\end{array}$ & \multicolumn{2}{|c|}{$\begin{array}{l}\text { The environment indicates the integration } \\
\text { of the systems in a broader context in the } \\
\text { future that utilizes intelligence function } \\
\text { towards the decision-making process for the } \\
\text { industry. }\end{array}$} \\
\hline $\begin{array}{c}\text { Supply Chain } \\
\text { Component }\end{array}$ & $\begin{array}{l}\text { Logistics, Procuren } \\
\text { Warehouse, Supplie } \\
\text { Development, } \\
\text { Shareholders. }\end{array}$ & $\begin{array}{l}\text { nent, Manufacturing, } \\
\text { rs, Sales and Product } \\
\text { Consumers and }\end{array}$ & \begin{tabular}{|lr}
\multicolumn{3}{|l}{ System Conversion, } \\
New Implementation, \\
Selective Data \\
Transition, \\
Information System \\
Drivers, and Industry \\
Drivers.
\end{tabular} & \multicolumn{2}{|c|}{$\begin{array}{l}\text { Knowledge-Based Economy, Creative } \\
\text { Content Development, IS Human Capital } \\
\text { Development, IS Infrastructure for } \\
\text { Intelligent SCM system and Source and } \\
\text { Procurement. }\end{array}$} \\
\hline
\end{tabular}

Table 4 indicates the subsystem for supply chain management based on VSM on the operation, management, and environment on the requirements of the industry performance. Moreover, the VSM model offers vital information on the system functions on supply chain management and ensuring the requisite variety for the industry performance. Therefore, we have designed an integrative and dynamic IS perspective model for supply chain management based on VSM, as shown in Figure 1.
Based on VSM, the current supply chain is analyzed in terms of decision-making capability. With the gained knowledge a complete recursive framework of a VSM will be developed. The framework allows the design of an Integrated Supply Chain System (ISCS) that meets all requirements of a dynamic environment. Flexible and adaptable ISCS processes can be developed for each identified subsystem of the VSM. 


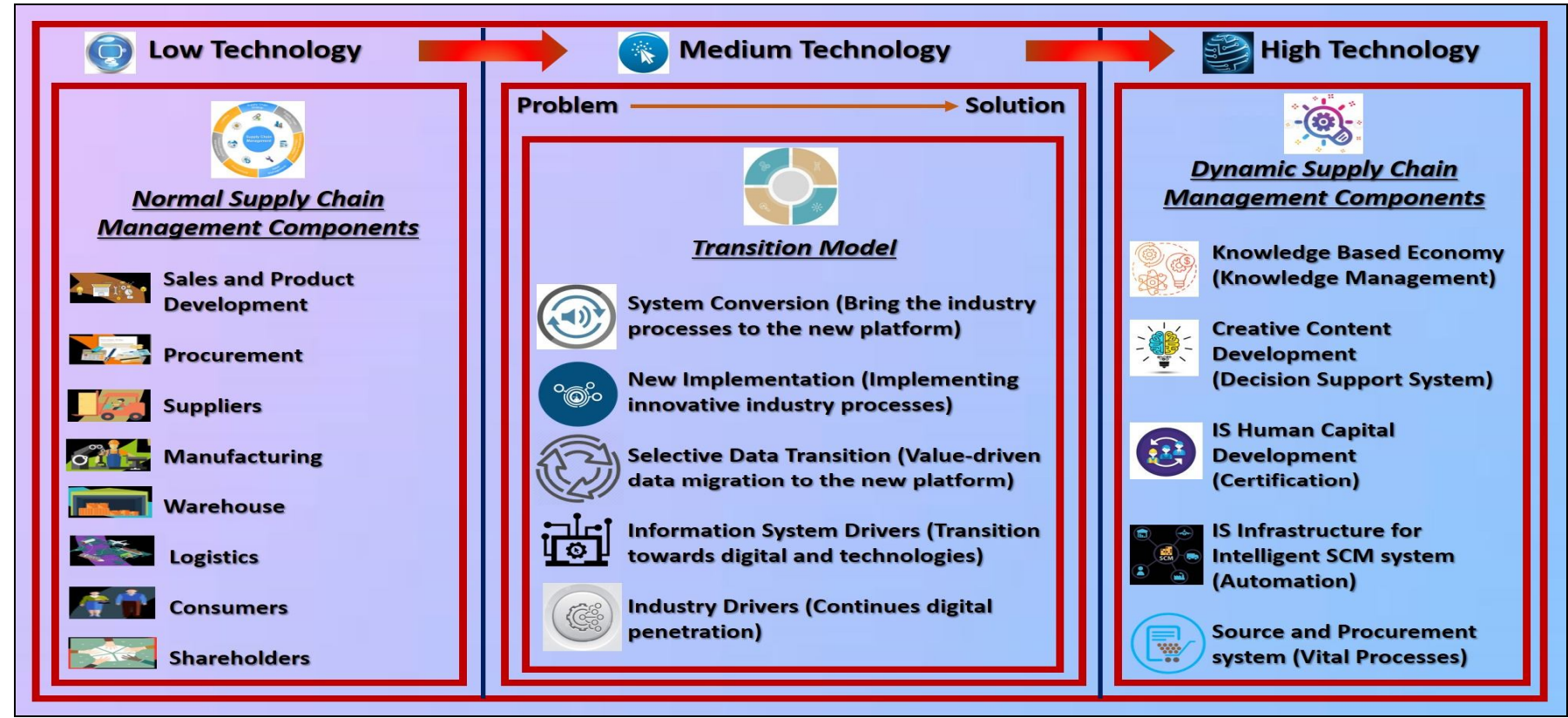

Figure 1: An integrative and dynamic IS perspective model for the supply chain management.

Based on Figure 1, the integrative and dynamic IS perspective model for supply chain management can be applied to RI for high-value precision-component industries that can optimize their decision-making process. Moreover, it also provides a virtual environment for the decision-making process by providing a dashboard monitoring system over the RI environment. Thus, this also enhances the RI position while simultaneously supporting profitability due to the new generation of digitalized systems in practice by adopting a new digital mindset.

\section{CONCLUSION}

Application of the IS approach in the RI supply chain management configuration as an internal structure that emphasis the holistic context of the industry. As far as IS and supply chain is concerned, this is influencing and supporting the strategic guidance of the industry direct the empathy of value-adding computerized IS. Since it combines, coordinates, and integrates with new technologies via the growth of holistic IS that enables and practices as a monitoring system for RI. Besides, it impacts the formation and develop new strategies through the learning process and handling information and knowledge technologies for better performance of the RI.

Based on the conceptualize presented in this paper, we focus on developing an integrative and dynamic IS perspective model that industry needed in their SCM towards digitalization value on enhancing productivity as IS push on analyzing performance trends and capabilities and leveraging IS as competitive pull on innovative IS that enabled application on obtaining divergent benefits in the marketplace to stay competitive as an optimal tool.

\section{ACKNOWLEDGMENT}

The authors would like to thank the reviewers and editor for their recommendation to strengthen the standard of this research paper. Our thanks are also forwarded to Universiti Teknikal Malaysia Melaka (UTeM) for the UTeM Zamalah Scheme for supporting and sponsorship this research work.

\section{REFERENCES}

[1] M. Saffree Jeffree, "Integrating Digital Health for Healthcare Transformation: Conceptual Model of Smart Healthcare for northern Borneo," Int. J. Adv. Trends Comput. Sci. Eng., vol. 9, no. 1, pp. 110-115, Feb. 2020.

https://doi.org/10.30534/ijatcse/2020/17912020

[2] W. Aprianto, "Analysis and Design of Web-Based Knowledge Management System for Real Estate Property," Int. J. Adv. Trends Comput. Sci. Eng., vol. 9, no. 1, pp. 1-7, Feb. 2020. https://doi.org/10.30534/ijatcse/2020/01912020

[3] M. Avital, L. Mathiassen, and U. Schultze, "Alternative genres in information systems research," Eur. J. Inf. Syst., vol. 26, no. 3, pp. 240-247, May 2017.

https://doi.org/10.1057/s41303-017-0051-4

[4] M. Jayakrishnan, A. K. Mohamad, and A. Abdullah, "Digitalization Approach Through An Enterprise Architecture For Malaysia Transportation Industry," Int. J. Civ. Eng. Technol., vol. 9, no. 13, pp. 834-839, 2018.

[5] M. Jayakrishnan, A. K. Mohamad, and A. Abdullah, "A Systematic Literature Review in Enterprise Architecture for Railway Supply Chain of Malaysia Transportation Industry," Int. J. Eng. Res. Technol., vol. 12, no. 12, pp. 2473-2478, 2019. 
[6] S. Sorooshian, "Information Technology for Supply Chain Management: Literature Review," Int. J. Adv. Trends Comput. Sci. Eng., vol. 9, no. 1, pp. 80-86, Feb. 2020.

https://doi.org/10.30534/ijatcse/2020/13912020

[7] J. Zdravkovic, J., Stirna, J. and Grabis, "A comparative analysis of using the capability notion for congruent business and information systems engineering.," Complex Syst. Informatics Model. Q., vol. 10, pp. 1-20, 2017.

[8] A. Saad and C. Dawson, "Requirement elicitation techniques for an improved case based lesson planning system," J. Syst. Inf. Technol., vol. 20, no. 1, pp. 19-32, Mar. 2018.

[9] V. U. T. Sfenrianto, Muhammad Jibril, Kaman Nainggolan, "Strategic Planning of Information Systems in a Timber Company," Int. J. Adv. Trends Comput. Sci. Eng., vol. 9, no. 1, pp. 274-278, Feb. 2020.

https://doi.org/10.30534/ijatcse/2020/41912020

[10] M. Jayakrishnan, A. K. Mohamad, and A. Abdullah, "Journey of an Enterprise Architecture Development Approach in Malaysian Transportation Industry," Int. J. Eng. Adv. Technol., vol. 8, no. 4, pp. 765-774, 2019.

[11] A. Khumaidi, "Design of Warehouse Management System for Fresh Product in Supply Chain Network," Int. J. Adv. Trends Comput. Sci. Eng., vol. 9, no. 1, pp. 308-314, Feb. 2020.

https://doi.org/10.30534/ijatcse/2020/47912020

[12] M. Jayakrishnan, A. K. Mohamad, and M. M. Yusof, "Understanding Big Data Analytics ( BDA ) and Business Intelligence ( BI ) Towards Establishing Organizational Performance Diagnostics Framework," Int. J. Recent Technol. Eng., vol. 8, no. 1, pp. 128-132, 2019.

[13] M. Jayakrishnan, A. K. Mohamad, and A. Abdullah, "Enterprise Architecture Embrace Digital Technology in Malaysian Transportation Industry," Int. J. Eng. Adv. Technol., vol. 8, no. 4, pp. 852-859, 2019.

[14] Y. Chang, S. F. Wong, U. Eze, and H. Lee, "The effect of IT ambidexterity and cloud computing absorptive capacity on competitive advantage," Ind. Manag. Data Syst., vol. 119, no. 3, pp. 613-638, 2019.

[15] G. S. Schiavi and A. Behr, "Emerging technologies and new business models: a review on disruptive business models," Innov. Manag. Rev., vol. 15, no. 4, pp. 338-355, Oct. 2018.

[16] M. Nehemia-Maletzky, T. Iyamu, and I. Shaanika, "The use of activity theory and actor network theory as lenses to underpin information systems studies," $J$. Syst. Inf. Technol., vol. 20, no. 2, pp. 191-206, May 2018.

https://doi.org/10.1108/JSIT-10-2017-0098

[17] M. Jayakrishnan, A. K. Mohamad, and A. Abdullah,
"The Taxonomy of Enterprise Architecture towards High Technology High Value Approach In Malaysian Transportation Industry," Int. J. Civ. Eng. Technol., vol. 9, no. 11, pp. 351-368, 2018.

[18] R. Mayer, N., Aubert, J., Grandry, E., Feltus, C., Goettelmann, E. and Wieringa, "An integrated conceptual model for information system security risk management supported by enterprise architecture management.," Softw. Syst. Model., pp. 1-28, 2018.

[19] Mokhtar, Information Systems \& Executives' Role. Utusan Publications, 2005.

[20] O. Noran and P. Bernus, "Business cloudification: An enterprise architecture perspective," 19th Int. Conf. Enterp. Inf. Syst. ICEIS 2017, vol. 3, pp. 353-360, 2017.

[21] W. Jiang, J., Klein, G. and Fernandez, "From project management to program management: an invitation to investigate programs where IT plays a significant role.," J. Assoc. Inf. Syst., vol. 19, no. 1, pp. 40-57, 2018.

[22] M. Jayakrishnan, “Analysis Of Socio-Technical Factors In Business Intelligence Framework Case Study Of Higher Learning Institution," Universiti Teknikal Malaysia Melaka, 2018.

[23] S. Singh, A., Agarwal, P., Dixit, S., Singh, S. and Sahai, "The transition towards sustainable supply chain management: an empirical study.," in In MATEC Web of Conferences, 2018, vol. 172, p. 05001.

[24] MITI, "Ministry of International Trade and Industry Report 2015," Minist. Int. Trade Ind., p. 144, 2016.

[25] J. Manners-Bell, Supply chain risk management: understanding emerging threats to global supply chains. Kogan Page Publishers., 2017.

[26] R. Cigolini, M. Pero, and A. Sianesi, "Reinforcing supply chain security through organizational and cultural tools within the intermodal rail and road industry," Int. J. Logist. Manag., vol. 27, no. 3, pp. 816-836, Nov. 2016.

https://doi.org/10.1108/IJLM-02-2014-0023

[27] C.-J. Chen, "Developing a model for supply chain agility and innovativeness to enhance firms' competitive advantage," Manag. Decis., vol. 57, no. 7, pp. 1511-1534, Jul. 2019.

[28] S. Laumer, C. Maier, and A. Eckhardt, "The impact of business process management and applicant tracking systems on recruiting process performance: an empirical study," J. Bus. Econ., vol. 85, no. 4, pp. 421-453, 2014.

https://doi.org/10.1007/s11573-014-0758-9

[29] B. Ivanov, D., Pavlov, A., Dolgui, A., Pavlov, D. and Sokolov, "Disruption-driven supply chain (re)-planning and performance impact assessment with consideration of pro-active and recovery policies.," Transp. Res. Part E Logist. Transp. Rev., vol. 90, pp. 7-24, 2016.

[30] I. Leng, K., Bi, Y., Jing, L., Fu, H.C. and Van 
Nieuwenhuyse, "Research on agricultural supply chain system with double chain architecture based on blockchain technology.," Futur. Gener. Comput. Syst., vol. 8, no. 6, pp. 641-649, 2018. https://doi.org/10.1016/j.future.2018.04.061

[31] A. Vahidi, A. Aliahmadi, and E. Teimoury, "Researches status and trends of management cybernetics and viable system model," Kybernetes, vol. 48, no. 5, pp. 1011-1044, May 2019.

[32] M. Schwaninger, "Governance for intelligent organizations: a cybernetic contribution," Kybernetes, vol. 48, no. 1, pp. 35-57, Jan. 2019.

[33] M. Orengo, "Theoretical notes regarding the practical application of Stafford Beer's viable system model," Kybernetes, vol. 47, no. 2, pp. 262-272, Feb. 2018.

https://doi.org/10.1108/K-02-2017-0069 